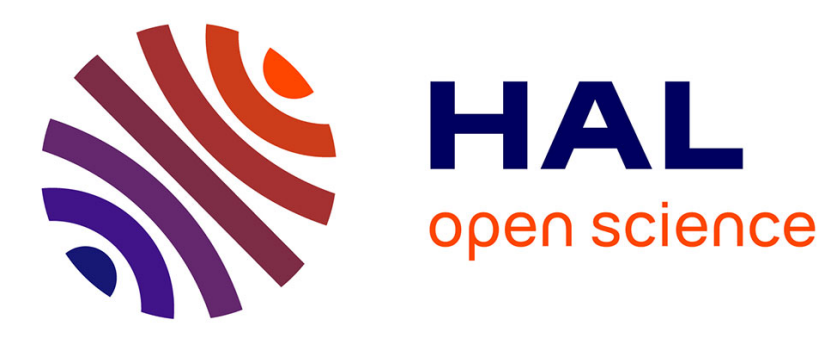

\title{
Pilot application of PalmGHG, the RSPO greenhouse gas calculator for oil palm products
}

Cécile Bessou, Laurence D. C. Chase, Ian E. Henson, Amir F.N.

Abdul-Manan, Llorenç Milà I Canals, Fahmuddin Agus, Mukesh Sharma, Melissa Chin

\section{To cite this version:}

Cécile Bessou, Laurence D. C. Chase, Ian E. Henson, Amir F.N. Abdul-Manan, Llorenç Milà I Canals, et al.. Pilot application of PalmGHG, the RSPO greenhouse gas calculator for oil palm products. Journal of Cleaner Production, 2014, 73, pp.136-145. 10.1016/j.jclepro.2013.12.008 • cirad-00938187

\section{HAL Id: cirad-00938187 http://hal.cirad.fr/cirad-00938187}

Submitted on 29 Jan 2014

HAL is a multi-disciplinary open access archive for the deposit and dissemination of scientific research documents, whether they are published or not. The documents may come from teaching and research institutions in France or abroad, or from public or private research centers.
L'archive ouverte pluridisciplinaire HAL, est destinée au dépôt et à la diffusion de documents scientifiques de niveau recherche, publiés ou non, émanant des établissements d'enseignement et de recherche français ou étrangers, des laboratoires publics ou privés. 


\title{
Pilot application of PalmGHG, the RSPO greenhouse gas calculator for oil palm products
}

\author{
Bessou C. ${ }^{a *}$, Chase L.D.C. , Henson I.E. ${ }^{\text {, }}$ Abdul-Manan A.F.N. ${ }^{\text {d, }}$ Milà i Canals L. ${ }^{\text {, }}$ Agus F. ${ }^{\text {, }}$ Sharma M. ${ }^{\text {, }}$,
} Chin M.

${ }^{a}$ Cirad, Perennial Crops Research Unit, Av. de l’Agropolis, TA B-34/02, F-34398 Montpellier Cedex 5, France

${ }^{\mathrm{b}}$ Independent Consultant in Tropical Agriculture, High Trees, Martineau Drive, Dorking, Surrey RH4 2PL, UK

${ }^{\mathrm{c}}$ Independent Consultant in Tropical Agriculture, Amberwood House, 6 Beaufort Road, Clifton. Bristol BS8 2JZ, UK.

${ }^{\mathrm{d}}$ Shell Global Solutions (Malaysia) Sdn. Bhd. Level 9, Bangunan Shell, Changkat Semantan, Damansara Heights, 50490 Kuala Lumpur, Malaysia.

e Safety and Environmental Assurance Centre, Unilever R\&D, Colworth Science Park, Sharnbrook, Bedfordshire, MK44 1LQ, UK

${ }^{\mathrm{f}}$ Indonesian Soil Research Institute, Ministry of Agriculture, Jl. Tentara Pelajar No. 12, Cimanggu Bogor 16114, Indonesia

${ }^{g}$ Asian Agri Group, R\&D Centre, PO Box 35, Kebun Bahilang' Tebing Tinggi Deli 20600, North Sumatera, Indonesia ${ }^{\text {h }}$ RSPO Secretariat Sdn Bhd., GHG Manager, Unit A-37-1, Level 37, Tower A, Menara UOA Bangsar, No.5, Jalan Bangsar Utama 1, 59000 Kuala Lumpur, Malaysia

* Corresponding author. Cécile Bessou; Phone: +33 46761 44 87; Fax: +33 4676165 90; Address: Cirad, Av. Agropolis, TA B-34/02, 34398 Montpellier Cedex 5; E-mail: cecile.bessou@cirad.fr

Retrieve the publisher online version at:

http://dx.doi.org/10.1016/j.jclepro.2013.12.008

\section{(Pre-proof version)}

\begin{abstract}
The Roundtable on Sustainable Palm Oil (RSPO) is a non-profit association promoting sustainable palm oil through a voluntary certification scheme. Two successive science-based working groups on greenhouse gas (GHG) were active in RSPO from 2009 to 2011, with the aim of identifying ways of achieving meaningful and verifiable reductions of GHG emissions. One of the outputs of the second group is PalmGHG, a GHG calculator using the life cycle assessment approach to quantify major sources of emissions and sequestration for individual palm oil mills and their supply base. A pilot study was carried out in 2011 with nine RSPO member companies that gave an average of $1.67 \mathrm{t} \mathrm{CO}{ }_{2} \mathrm{e} / \mathrm{t} \mathrm{crude}$ palm oil (CPO), with a range of -0.02 to $+8.32 \mathrm{t}$ CO2e/t CPO. Previous land use and the area of peat soil used were the main causes of the variation. Further modifications to PalmGHG continue to be made in order to make the tool more flexible and comprehensive, to refine default values, and to render it more user-friendly.
\end{abstract}

Keywords: Palm Oil, GHG, Calculator, RSPO, Scenario testing 


\section{Introduction}

Palm oil is now the most used vegetable oil worldwide, accounting in 2011 for $31.3 \%$ of the global oils and fats production (Oil World, 2012). About 10\% of global production is certified by RSPO, the Roundtable on Sustainable Palm Oil (Oil World, 2012; RSPO, 2013). RSPO is a non-profit association created in 2003 and legally registered in 2004. It promotes the production and consumption of sustainable palm oil through a voluntary certification scheme. This certification scheme was developed by the stakeholders of the seven sectors involved in the palm oil commodity chain: growers, processors/traders, social NGOs, environmental NGOs, manufacturers, retailers, and banks. It relies on the growers and processors for compliance with 39 principles and criteria ${ }^{1}$ (P\&Cs) of sustainability that were defined by consensus in $2007^{2}$. RSPO is directed by an executive board (EB), the highest RSPO authority, which plays a major role in organising an annual general assembly and supervising member groups. During 2009-2011, the EB commissioned two successive science-based working groups on greenhouse gas (GHG WG) tasked with the aim of identifying ways leading to meaningful and verifiable reductions in GHG emissions.

Within the framework of P\&Cs revision, the GHG WG2 recommended to the EB the use of PalmGHG (Chase et al., 2012), a GHG calculator that allows producers to calculate the GHG balances of oil palm products. PalmGHG was developed by the GHG WG2 as an Excel spreadsheet using the life cycle assessment approach. It is based on a tool developed previously by Chase \& Henson (2010). PalmGHG quantifies the major sources of emissions and sequestration for a palm oil mill and its supply base, and is thus consistent with the operation of the certification scheme. The calculator is flexible, allowing for different crop rotation lengths and use of alternative default values. It calculates the total net emissions per ha, allocates these to

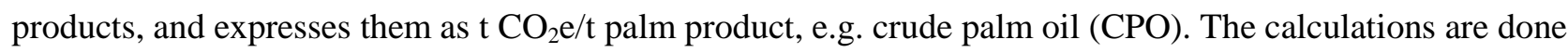
annually: allowing for identification of principal emission sources for management purposes and for regular reporting, and communication across the supply chain and with interested parties.

This paper presents briefly the structure and content of PalmGHG Beta version 1.a (of December 2012), and focuses on the results from the pilot phase of PalmGHG carried out in 2011 with nine RSPO companies. Identified needs for further research and PalmGHG improvements are also stressed.

\section{Material and methods}

\footnotetext{
${ }^{1}$ The 39 RSPO P\&Cs cover 8 dimensions:1) Commitment to transparency [2 criteria], 2) Compliance with applicable laws and regulations [3 criteria], 3) Commitment to long-term economic and financial viability [1 criterion], 4) Use of appropriate best practices by growers and millers [8 criteria], 5) Environmental responsibility and conservation of natural resources and biodiversity [6 criteria], 6) Responsible consideration for employees and for individuals and communities affected by growers and mills [11 criteria], 7) Responsible development of new plantings [7 criteria], and 8) Commitment to continuous improvement [1 criterion].

${ }^{2}$ In 2012 the first revision of the P\&C took place (this process is planned for every 5 years); at the moment this manuscript was written the proposed revision of the P\&C was due to be voted in April 2013.
} 


\subsection{PalmGHG approach and boundaries}

The PalmGHG calculator is based on a Life Cycle Assessment (LCA) approach; it is hence in line with LCA international standards, i.e. ISO 14040 and 14044. It is more specifically based on an attributional LCA approach (Zamagni et al., 2012) (i.e. the impacts are those linked to the production unit without considering marginal impacts on other productions or any feedback mechanisms), it thus notably excludes indirect land use changes. Indirect land use changes are still not included in most international standards (IPCC, PAS2050, ISCC, GHG Protocol Product Standard, etc.). While LCA norms provide a harmonised global framework to assess environmental impacts over a supply chain, IPCC guidelines provide specific algorithms and emission coefficients to specifically calculate the GHG balance. PalmGHG, like most international GHG accounting standards such as ISCC or PAS2050, is hence based on IPCC (2006). Net GHG emissions due to direct land use change are calculated according to IPCC (2006) and hence account for provisional stocks in the vegetation biomass. Further details on specificities related to perennial cropping systems were provided in PAS2050 by BSI, 2011 (see section 2.2.1).

PalmGHG is a significant development of the GWAPP ${ }^{3}$ model of Chase and Henson (2010) which, while straightforward to use, has a number of limitations in that palms are assumed to have an even age distribution, no allowance is made for variations in inputs and outputs within the palm area, and several aspects involve modelling rather than being based on field data. These limitations were addressed and the model simplified by assessing only the main sources of emissions and sequestration, and by using as much field data as possible, resulting in a smaller, more flexible, and more site-specific calculator. The following description of PalmGHG content is relevant for PalmGHG Beta version 1.a (of December $2012^{4}$ ).

PalmGHG provides an estimate of the net GHG emissions produced during the palm oil production chain. The emissions are presented as $\mathrm{CO}_{2}$ equivalents $\left(\mathrm{CO}_{2} \mathrm{e}\right)$. Following the IPCC guidelines (IPCC, 2006), the GHGs considered are $\mathrm{CO}_{2}, \mathrm{~N}_{2} \mathrm{O}$, and $\mathrm{CH}_{4}$. Conversion factors to give $\mathrm{CO}_{2} \mathrm{e}$ (global warming potentials) are those determined by IPCC (2007), and correspond to a 100 year timeframe; i.e. $298 \mathrm{~kg} \mathrm{CO}_{2} \mathrm{e} / \mathrm{kg} \mathrm{N}_{2} \mathrm{O}$ and 25 $\mathrm{kg} \mathrm{CO} 2 \mathrm{e} / \mathrm{kg} \mathrm{CH}_{4}$. The conversion factor for biogenic $\mathrm{CH}_{4}$ is calculated from the ratio of the molecular weights of $\mathrm{CO}_{2}$ and $\mathrm{CH}_{4}$ to account for the released $\mathrm{CO}_{2}$ originating from photosynthetic fixation; i.e. a global warming potential of $22.25 \mathrm{~kg} \mathrm{CO}_{2} \mathrm{e} / \mathrm{kg} \mathrm{CH}_{4}$ (Wicke et al., 2008).

Net GHG emissions are calculated by adding the emissions released during land clearing, crop production and crop processing, and subtracting from these emissions the sequestration of carbon in the standing crop and conservation areas. The system boundary is shown in Figure 1. In the first step, net emissions are calculated as tonnes of $\mathrm{CO}_{2} \mathrm{e}$ per hectare. From the yield of Fresh Fruit Bunches (FFB) and the extraction rates in the mill, product-specific emissions are calculated per tonne of Crude Palm Oil (CPO) and per tonne of Palm

\footnotetext{
${ }^{3}$ GWAPP : Global Warming Assessment of Palm Oil Production

${ }^{4}$ PalmGHG may be downloaded under request on the webpage: http://www.rspo.org/en/rspo_palmghg_calculator
} 
Kernel (PK). Allocation of the net emissions of $\mathrm{CO}_{2} \mathrm{e}$ between the various products of interest $\mathrm{CPO}$ and $\mathrm{PK}$, and subsequently between Palm Kernel Oil (PKO) and Palm Kernel Expeller (PKE), is carried out according to the extraction rates of each mill. However, allocation factors based on the energy contents of oils and coproducts may be also provided in future programmed versions of PalmGHG, in order notably to compile PalmGHG results with further assessments up to biodiesel production within the RED (European Commission, 2009). System expansion is otherwise parameterised for valued co-products getting out of the system, i.e. excess electricity from burning fibre and shell or methane capture. No emission burdens are calculated for co-products recycled within the system. However, should these internally recycled co-products be exported, further system expansion scenarios should be implemented.

The emission sources included in the calculator are:

i) Land clearing;

ii) Manufacturing, transport and use of fertilisers;

iii) Nitrous oxide and carbon dioxide resulting from the field application of fertilisers and mill coproducts;

iv) Fossil fuel used in the field, mainly for harvesting and collection of FFB;

v) Fossil fuel used at the mill;

vi) Methane produced from palm oil mill effluent (POME); and

vii) Carbon dioxide and nitrous oxide resulting from the cultivation of peat soils.

In addition, the following GHG fixation and carbon credits are also considered:

i) Carbon dioxide fixed by oil palm stand, ground cover and in plantation litter;

ii) Carbon dioxide fixed by biomass in conservation areas (methodology still under development and discussion);

iii) GHG avoided by the selling of mill energy co-products (e.g. electricity sold to the grid; palm kernel shell sold to industrial furnaces).

These ten items account for the bulk of the GHG emissions and fixation occurring during the oil palm crop cycle (Chase and Henson, 2010). Items that are not included in the budget are the nursery stage, pesticide use, fuel used for land clearing, emissions embodied in infrastructures and machines, and the sequestration of carbon in palm products and co-products. These items are generally negligible GHG sources or sinks (Schmidt, 2007; Choo et al., 2011). The other emissions are particularly small when annualised over the crop cycle.

Provision is made for separate budgets for a mill's own crop (produced on estates that belong to the same company as the mill) and outgrower crop (such as produced by independent or contracted farmers who are smallholders). PalmGHG uses the annualised emission and sequestration data to estimate the net GHG balance for the palm products from both own and outgrower crops at an individual mill. Emissions from the bi- 
omass cleared at the beginning of the crop cycle are averaged over the cycle. Emissions from the other sources are averaged over the three years up to and including the reporting date, thus simplifying data collection and smoothing out short-term annual fluctuations. The estimates can be updated on a yearly basis to reflect changes in operating conditions and the growth and age distribution of palms.

\section{INSERT FIGURE 1 ABOUT HERE}

\subsection{Scientific background}

The scientific background is detailed in Chase et al. (2012), but some insights on the main assumptions are given in this paper. Emphasis was put on using the most updated equations and data relevant for palm oil production systems and tropical agricultural conditions.

\subsubsection{Land use change}

The approach used to evaluate the contribution of land use and land use change (LULUC) to net GHG emissions is based on the Stock-Difference Method of IPCC (2006) Tier 1. The time interval to assess the stock-difference corresponds to the average crop cycle length. The latter is defined by the user and can differ between own-crop and out-grower areas, as well as between plantations on mineral or peat soils. It usually slightly varies around 25 years, which is set as default value. Carbon stocks considered in the various land uses include both above- and below-ground biomass. Changes in soil organic matter in mineral soils might be significant in the long term but were not considered as the evidence concerning such change is limited and contradictory especially in the long term (Soussana et al., 2004; Seguin et al., 2007; Germon et al., 2007).

Areas planted each year with a breakdown of previous land uses are recorded. Based on literature data, values for eight previous land uses and oil palm stands are currently available in PalmGHG (Table 1). Additional previous land uses, such as primary forest or shrub, should be implemented soon following a review process by experts under the supervision of RSPO GHG secretariat. User-defined previous land uses may also be implemented provided evidence of field measurements and a validation by experts based on a dedicated guidance by RSPO GHG secretariat. Emissions arising from land clearing are calculated based on measured carbon contents or in their absence on an assumed carbon content of $45 \%$ in the biomass of the previous vegetation.

In agreement with Stock-Difference Method of IPCC (2006), carbon stock in crop stand is accounted for, i.e. the incremental carbon that is fixed in the oil palm stand over the whole crop cycle of about 25 years. It corresponds to some threshold also provided in PAS2050 (BSI, 2011). Carbon fixed in palm products (oils) and co-products (fibre, shell etc.) is too short-lived to be accounted for (BSI, 2011). Given the emphasis on gathering accurate data on oil palm agronomy, carbon sequestration in the oil palm stand are modelled with 
OPRODSIM $^{5}$ and OPCABSIM ${ }^{6}$ models (Henson, 2005; 2009), which are specifically designed to estimate oil palm stand biomass largely based on Malaysian conditions. The total amount of carbon sequestered in the reporting year is calculated by multiplying the area of each year of planting by the amount of carbon sequestered, adding these together, and dividing by the total area to give $\mathrm{C} / \mathrm{ha} / \mathrm{yr}$. Field observations revealed that biomass growth and yields are generally lower in the case of out-growers (Chase and Henson, 2010; Khasanah et al., 2012). To reflect this difference, contrasting simulation scenarios of crop sequestration can be used as default estimates within PalmGHG for mill own crops and out-growers. A "vigorous growth" simulation model is considered for own crops, and an "average growth" simulation is used for out-growers. Alternative models exist (van Noordwijk et al., 2010; updated by Khasanah et al. 2012; Asmara et al., 2012). These models, as well as potential allometric measurements carried out by the user, may be further implemented in future versions of PalmGHG to account better for management impacts on the biomass stand.

\subsubsection{Field emissions}

Emissions due to fertilisers contribute significantly to total agricultural GHG emissions and so affect the final GHG balance of palm oil (Yusoff and Hansen, 2007; Pleanjai et al., 2009; Arvidsson et al., 2011; Choo et al., 2011). Therefore, they have been accorded special attention in PalmGHG. $\mathrm{N}_{2} \mathrm{O}$ direct and indirect field emissions are calculated according to IPCC Tier 1 (IPCC, 2006). Following the same guidelines (IPCC, 2006), $\mathrm{CO}_{2}$ emissions from urea application which is subject to volatilisation losses are also accounted for. Provision is given for nine widely used synthetic fertilisers and two organic ones (Empty Fruit Bunches, EFB, and POME) but additional fertiliser types can be included by the users if required. Methane emissions due to POME are accounted for at the mill stage and vary according to the type of treatment. Calculations of $\mathrm{CH}_{4}$ production and amounts and losses during digestion, flaring, or electricity production are based on factors from Schmidt (2007) and the Environment Agency (2002). Radiative forcing of $\mathrm{CH}_{4}$ from POME accounts for its biogenic origin (Wicke et al., 2008) and is set to zero when $\mathrm{CH}_{4}$ is flared and converted to $\mathrm{CO}_{2}$.

Finally, both $\mathrm{CO}_{2}$ and $\mathrm{N}_{2} \mathrm{O}$ emissions related to peat soil cultivation are included in the assessment. $\mathrm{N}_{2} \mathrm{O}$ emission factor is taken from Tier 1 IPCC (2006), i.e. $16 \mathrm{~kg} \mathrm{~N}-\mathrm{N}_{2} \mathrm{O} / \mathrm{h}$.year. $\mathrm{CO}_{2}$ emissions are based on the results of the RSPO Peatland Working Group, which placed emphasis on the importance of managing the water table depth to limit peat soil subsidence and related $\mathrm{CO}_{2}$ emissions. $\mathrm{CO}_{2}$ emissions due to peat cultivation are hence currently calculated using Eq. 1 (Hooijer et al., 2010), and vary with water table management. However this may be revised in the future to better account for further management practices and better differentiate peat oxidation and root respiration. In PalmGHG a default drainage depth when water table is actively managed is set to $60 \mathrm{~cm}$, considered, as good management practice (RSPO, 2012) to be the maximum

\footnotetext{
${ }^{5}$ Oil Palm Production Simulator

${ }^{6}$ Oil Palm Carbon Budget Simulator
} 
water level to be maintained below the peat surface. From Eq. 1 this leads to annual emissions of $54.6 \mathrm{t} \mathrm{CO}_{2} / \mathrm{ha}$.

Peat $\mathrm{CO}_{2}$ emission $\left(\mathrm{t} \mathrm{CO}_{2} /\right.$ ha.year $)=0.91 \mathrm{x}$ Drainage depth $(\mathrm{cm})$

Eq. 1

Further research is needed to better define how agricultural management and in particular water table management might influence the amount of $\mathrm{CO}_{2}$ and $\mathrm{N}_{2} \mathrm{O}$ emissions linked to peat cultivation (RSPO, 2012).

PalmGHG is a flexible tool and options are given to change default parameters. For instance, the crop cycle length can be adapted. It can notably be changed to reflect differences between crops on mineral soils and those on peat soil, which are often shorter due to accentuated sensitivity to pest and diseases and poor anchorage of palm roots (Wetlands International, 2010).

\section{INSERT TABLE 1 ABOUT HERE}

\subsubsection{Mill emissions}

At the mill level, two main sources of GHG emissions are present, fossil fuel consumption and methane emission from POME, although only the latter is significant at the supply chain level (Pleanjai et al., 2009; Choo et al., 2011). POME emissions vary depending on its treatment, i.e. conventional digestion, flaring or conversion to electricity. Parameters to account for the impact of the various treatment options are provided based on Yacob, et al. 2005,2006; Schmidt, 2007. Given the field variability of some of these key parameters, e.g. the amount of POME per tonne of fresh fruit bunches processed or the amount of methane emitted per tonne of POME treated, further development of PalmGHG might include new parameters to better define POME emissions according to detailed treatment practices (including potential co-composting).

\subsection{The pilot process}

PalmGHG is a GHG calculation tool that aims to help palm oil producers to identify GHG hotspots as well as management options to reduce these emissions. To this end, the content and format of the tool were discussed by scientists and supply chain stakeholders for about two years. We reached compromises combining consistent scientific background with practical knowledge from the producers. The system boundary encompasses the whole supply area of one mill, which is the certification unit and hence the management unit too. The format of input data was also agreed in order to ease data collection and yearly update, while seeking for a sound smoothing-out of intrinsic variability. Default values are provided in order to ensure the consistency of the calculation, but options are given to the user to implement actual data, which shall help to better account for actual management options. As much as possible, parameters linking detailed practices with emission determinism were introduced in order to identify management control levers. Finally, the results are ex- 
pressed in disaggregated units in order to manage GHG emissions at several levels, while avoiding problem shifting.

A pilot study was carried out with nine RSPO companies. This pilot phase was crucial both to check for the consistency of the tool, especially in terms of data availability, and to determine the ease of use and suitability of PalmGHG as a management tool. In June 2011, a preliminary questionnaire was sent to correspondents from the pilot companies. This questionnaire was the starting point of correspondence between these companies and RSPO appointees who were responsible for guiding company correspondents in the use of PalmGHG. The questionnaire aimed to introduce PalmGHG to the correspondents and help them to define the boundaries for the chosen mills and identify the data needs. Mail exchanges, as well as field visits, assisted the compilation of input data and calculation of GHG balances. The correspondents and RSPO appointees worked in parallel on PalmGHG with the same data sets to allow for cross-checking and trouble shooting. Results were presented to all the stakeholders during the annual RSPO conference in November 2011.

\section{Results}

\subsection{PalmGHG pilot results}

Results from ten mills are presented in this paper (Table 2). The nine companies involved in the pilot provided data for several of their mills so that complete data sets were finally consolidated for ten mills in total. The studied mills cover the main worldwide producing countries, i.e. Indonesia, Malaysia, as well as Brazil and Papua New Guinea. The average GHG balance was $1.67 \mathrm{t} \mathrm{CO}_{2} \mathrm{e} / \mathrm{t} \mathrm{CPO}$, and ranged from -0.02 to $+8.32 \mathrm{t} \mathrm{CO}_{2} \mathrm{e} / \mathrm{t} \mathrm{CPO}$. Main hotspots of emissions were land clearing, peat oxidation, fertiliser-related emissions (embodied emissions in fertiliser production and field emissions) and methane from POME. Across the mills without supply from peat area, land clearing represented $41-80 \%$ of total emissions, POME represented $15-35 \%$ of total emissions, and fertiliser-related emissions represented 3-19\% of total emissions. Field emissions are a common hotspot in GHG assessment of agricultural productions due to fertiliser use, and adding land clearing emissions reinforces the overall weight of the field emissions. In the case of palm oil, these two hotspots are even more important that field operations are mostly done by hand (e.g. organic fertiliser application, harvest). In the pilot mills, fossil fuel used in the field only contributed to $0-5 \%$ of total emissions. Fuel use at the mill stage also was very limited ( $0-2 \%$ of total emissions) due to the recycling of co-products to produce heat and power. The main GHG source at the mill stage was methane emissions from POME. At the time of the assessment, none of the pilot mills was capturing methane from the POME digestion to flare it or convert it to electricity. Currently, only $10 \%$ of the mills in Malaysia and Indonesia have the installation to capture methane from effluent digestion (EPA, 2012). The contribution of the various emission sources and sink are shown for mill $\mathrm{H}$ in Figure 2. 
In the cases where fruits were supplied from peat land area, $\mathrm{CO}_{2}$ and $\mathrm{N}_{2} \mathrm{O}$ emissions due to peat cultivation became overwhelming. For the two mills encompassing significant peat area in their supply area, $\mathrm{CO}_{2}$ and $\mathrm{N}_{2} \mathrm{O}$ from peat cultivation accounted for $62-77 \%$ and $8-10 \%$ of total emissions; respectively. Extreme values of the observed range of GHG balances are hence explained by peat emissions on the one end, and by land use change on the other end. Indeed, negative GHG balances can be reached if biomass stand in previous land uses was lower than that of palm oil stand, while other sources of emissions remain relatively low (i.e. notably without peat emissions). Among the pilot mills, which all had identical POME treatment, previous land use and the percentage of the area on peat soil were the main causes of GHG balance variation.

\section{INSERT TABLE 2 ABOUT HERE}

\section{INSERT FIGURE 2 ABOUT HERE}

Data for outgrowers were available for five mills. On a hectare basis, contribution of outgrowers to annual supply varied between $2-29 \%$ with a median value of $7 \%$. Fruit yields are generally lower in plantations of outgrowers than own crops due to non-selected planting material and less efficient fertiliser management (Bessou et al., 2012; Harsono et al., 2012). In the pilot mills, yields of outgrowers’ plantations were between 4-60\% lower than those of own crops. Impact on the GHG balance at the field level was however more affected by the differences in previous land uses and the proportion of peat land in own crops (Fig. 3). In the pilot, outgrowers were not cultivating peat soils and primarily planted palms after arable crops or grassland.

\section{INSERT FIGURE 3 ABOUT HERE}

\subsection{Scenario testing}

PalmGHG readily allows manipulation of input data to test management interventions. Results of scenario testing are given for a set of dummy data for a base case with the following characteristics: mixed previous land uses, 3\% of the area containing peat, no POME treatment, OER 20\%, own crops mean yield 20 t FFB/ha, outgrowers' mean yield 14 t FFB/ha (Scenario 1 in Figure 4). The base case scenario (1) represents a virtual mill with widespread characteristics for common mills in Indonesia and Malaysia, the first world producing countries. It was established by experts who have decades of experience in oil palm agronomy and data collection at field and mill levels. This base case scenario and the tested scenarios are very likely to represent existing cases and to address most pregnant interrogations for future plantations (e.g. what it the influence of previous land uses on the GHG balance?: scenarios 2-3), for operating mills (e.g. what is the GHG saving potential through capture and conversion of methane?: scenario 4), and for replanting since main palm plantations in these countries are in their third to fourth generation (e.g. what are the best options to replant with a GHG balance close to zero?: scenario 5). 
The results show that high emissions result from clearing logged forest, and conversely that very low (negative) emissions result from clearing low biomass land such as grassland on mineral soils. Fertiliser emissions, including both upstream and field emissions are a not negligible contributor, especially in scenario 3 where net sequestration (sequestration minus land clearing emissions) is high, and in scenarios 4 and 5, where net sequestration is almost null and methane is captured.

The contribution of mill fuel is negligible and not visible on the graph. Net emissions below $0.3 \mathrm{t} \mathrm{CO} 2 \mathrm{e} / \mathrm{t} \mathrm{CPO}$ can thus be obtained from a mature industry that is replanting palms, capturing methane and generating electricity from the biogas (Scenario 5 in Figure 4). This was highlighted in recommendations of the RSPO GHG WG2 to the RSPO EB within the frame of P\&Cs revisions.

\section{INSERT FIGURE 4 ABOUT HERE}

\subsection{Feedback from users}

The main difficulties encountered by the pilot companies were related to data collection. Some difficulties may diminish as the recording process becomes routine. However, collecting data from outgrowers may remain a problem unless they are guided in the processes of data collection and PalmGHG use.

Correspondents from the pilot companies were reactive and provided feedback on the design and the ease of use of PalmGHG. Some modifications have already been implemented, but the following points still need further consideration: 1) use of graphs to help visualise the effects of adjusting key variables; 2) allowing for a more immediate way to change crop lifespans; 3) incorporation of further routines to calculate the standing biomass of crops and natural vegetation; 4) incorporation of additional fertiliser types such as compounds and mixtures; and 5) identification of further reliable peat emission parameters. These further developments will be made possible through both software programming and continuous research effort on improving the science basis behind emission factors and process modelling.

\section{Discussion}

GHG balances calculated with PalmGHG are within the range of those found in the literature. However, depending on the system boundaries and particularly on assumptions regarding land clearing and peat emissions, estimated GHG balances vary greatly around $2.3 \mathrm{t} \mathrm{CO}_{2} \mathrm{e} / \mathrm{t} \mathrm{CPO}$ (Schmidt, 2007), from 0.6$1 \mathrm{t} \mathrm{CO} \mathrm{e}_{2} \mathrm{e}$ CPO (Siangjaeo et al., 2011), or 2.8-19.8 t CO $\mathrm{CO}_{2} \mathrm{e}$ CPO (Reijnders and Huijbregts, 2008). In previous studies, the relative importance of different sources of GHG emission was shown to be similar; land clearing and the cultivation of peat soils are the two most important contributors (Germer and Sauerborn, 2008; Reijnders and Huijbregts, 2008; Wicke et al., 2008). Some studies that do not directly address them still mention the primary importance of these factors (Yusoff and Hansen, 2007; Pleanjai et al., 2009; Stichnothe and Schuchardt, 2011). In all studies methane from POME and fertiliser production and use are also 
important contributors (Choo et al., 2011; Pleanjai et al., 2009; Siangjaeo et al., 2011), although their relative importance depends on whether land use change and peat emissions are included. As shown in the PalmGHG scenario tests, it is often emphasised that methane capture can result in significant GHG reductions in comparison with open-pond POME treatment, e.g. of between 30 to 50\% (Vijaya et al., 2008; Chuchuoy et al., 2009).

Carbon stocks in biomass stands and peat emissions are very sensitive parameters. Research efforts are still needed to better quantify carbon stocks and impacts of agricultural practices on these stocks, especially in the case of peat cultivation. As highlighted by Couwenberg (2011), IPCC coefficients for GHG emissions from managed peat soils may be still too low. Thanks to the work of the RSPO Peatland Working Group, some management factor could be introduced within PalmGHG to account for the impact of the depth of drainage on peat oxidation. It already allows for the producers to see the impact of peat management on GHG emissions in order to foster best practices implementation. However, further improvement is needed to better model the impact of peat management on the various GHG emissions. This is of paramount importance in Southeast Asia where peat lands represents $57 \%$ of the tropical peat area and $77 \%$ of the tropical peat carbon pool (10-14\% of the global peat carbon pool). A great part of tropical peat land area is furthermore located in the two top palm oil producing countries, Indonesia with 21 million ha (65\%) and Malaysia with 2.6 million ha (10\%) (Page et al., 2011).

We acknowledge that the modelling of LULUC impact on the GHG balance is not sensitive to the actual residence time of carbon in the various land uses. The debate around timing of emissions and removals in LCA has been on-going for the last twenty years or so, and is clearly reviewed in Cherubini et al. 2012. Authors generally agree on the need to account for the complete carbon cycle including biogenic carbon (Rabl et al. 2007; Müller-Wenk and Brandão, 2010, etc.), but methodologies vary. Straight-line amortisation of pulse emissions are widely found both in scientific papers (Searchinger et al., 2008; Gnansonou et al., 2009) and methodological guidelines (IPCC, 2006; EU, 2009; PAS2050, 2011), while more dynamic approaches such as time-distributed or delayed emissions have been also developed notably within the LCA framework (Kendall et al., 2009; Müller-Wenk and Brandão, 2010; Cherubini et al., 2011). As highlighted by some authors, time horizons or time preference in GHG assessments can have a great influence on the final balance (Searchinger et al., 2008; Cherubini et al., 2011); but they are more related to policy choices rather than a scientific question (Fearnside, 2002). Time horizons already are intrinsically embedded in global warming potentials provided by IPCC (2006) and correspond to a 0.9\% annual discount rate, i.e. no preference for time (Fearnside, 2002; Cherubini et al. 2012). We argue that a dynamic accounting for the carbon cycle at the global level would be more scientifically robust but is, for the moment, not in agreement with IPCC methodologies (both the guidelines and global warming potentials). It does neither address the issue of irreversible losses. We also argue that it is a policy issue to allocate the burden of land clearing to the immediate following land use, while driven development factors for a specific land area might be assessed at a more national or even global level. A dynamic accounting for the carbon cost would make PalmGHG rather complex 
for the users, while producers already had difficulty to adopt the tool due to the policy argument on the above-mentioned development issue related to land clearing. PalmGHG is a management tool that allows for comparing production systems with different management practices. It correctly points to main emission sources and gives incentives to limit land clearing or peat cultivation for instance in order to reduce GHG emissions. Given the mentioned shortcomings, we want to stress that PalmGHG does not provide absolute GHG balances but estimates that are suitable to adapt the practices towards sustainable systems. The RSPO criterion on GHG monitoring comes together with further requirements such as conservation of High Conservation Value areas, which are a more efficient tool to limit irreversible losses such as biodiversity ones. The idea behind "conservation area” included in the GHG balance is to give further incentive to preserve land area also from a GHG point of view. However, the methodology to measure the carbon savings and include the estimates in the GHG balance has not yet been established. It will face the same issue for biogenic carbon and should be peer-reviewed before being implemented in PalmGHG.

Integrating the spatial and temporal dimensions of the perennial palm crop cycle within a snapshot assessment is not immediate. In PalmGHG, this difficulty is partly overcome by considering data from all oil palm plantings within the whole supply area. Despite the large areas that are often involved, the ages of the oil palms may not be evenly distributed and this may bias the assessment.

Several studies have focused on the treatment and uses of co-products (Yacob et al., 2005; Chavalparit et al., 2006; Vijaya et al., 2008; Stichnothe and Schuchardt, 2011). However, the implementation of these technologies involves high capital costs which may restrict their uptake by producers. In addition, there may be limited options for the sale of excess energy especially when grid connection is not possible. However, such technologies can be implemented through clean development mechanisms provided care is taken to avoid double-counting of GHG savings, such as the credits for coal substitution by sale of shell. Moreover, more research effort is needed to better assess fertilising efficiency of land clearance residues and environmental emissions of down-stream processes related to co-product treatment and transport.

The GHG balance is only one of several potential impacts of palm oil production on the environment. However, it has yet to be fully accorded due importance as part of RSPO P\&C. In this respect, PalmGHG is a useful tool that can help identify potential GHG savings at the plantation and mill. Together with the other RSPO P\&Cs that represent a broader view of sustainability criteria, it can help improve the image of oil palm production by openly accounting for its $\mathrm{C}$ footprint and demonstrating improvements leading to greater sustainability.

Compared to other vegetable oils, palm oil and its derivatives usually perform better in terms of GHG balance due to their high yields per hectare. Thus for rapeseed oil Schmidt (2007) reported 517 t CO $2 \mathrm{e} / \mathrm{t}$ Rapeseed oil and Thamsiriroj and Murphy (2009) and Achten et al. (2010a, b) calculated 39$88 \mathrm{~g} \mathrm{CO}_{2} \mathrm{e} / \mathrm{MJ}$ Palm Methyl Ester compared to 62 and 124-159 g CO $2 \mathrm{e} / \mathrm{MJ}$ for rapeseed and Jatropha Methyl 
Ester respectively. However, comparisons using a single criterion may induce problem shifting in environmental impacts. More comprehensive LCAs must also be undertaken to quantify other environmental impacts and allow for a sounder and more harmonised comparison between the different agricultural products including land transformation and land occupation compared to reference land uses (Milà i Canals et al. 2013). In particular, consideration of impacts on soil fertility and biodiversity is paramount. In this case, other stages of palm oil production might also play an important role such as the use of pesticides causing ecosystem toxicity or boiler emissions affecting human health (Schmidt, 2007; Choo et al., 2011; Bessou et al., 2012).

\section{Conclusions}

PalmGHG is a comprehensive GHG calculator representative of the state of the art in terms of available data and international methodologies for GHG accounting. Emphasis has been placed on information directly relevant to palm oil production that should be easily available at the field and mill levels. However, provision is also made for data which might not be available by their substitution with representative default data. Flexibility is an important feature of PalmGHG, with options that allow for alternative calculations and methodology.

During pilot testing it was shown that PalmGHG can identify GHG emission 'hot spots', and so help to define GHG reduction strategies. Feedback from the pilot companies highlighted problems in collecting data, especially those for three consequent years. It should, however, be noted that difficulties related to data recording will progressively diminish once the monitoring of GHG emissions becomes routine. PalmGHG is being reprogrammed to make it more user-friendly in terms of data entry and output display. The new software will allow for the users to quickly generate results and yearly update the database, while being able to readily change default parameters and easily undertake tests of alternative scenarios. On the other hand, difficulties encountered when collecting data for outgrowers are not so easily resolved and indicate a need for a specific strategy to help them record and collect data on a routine basis.

The results of the pilot and scenario tests provide an important information base on which to make recommendations to the RSPO EB and to communicate to a larger audience the work of the RSPO GHG WG and the use of PalmGHG. Further recommendations of the GHG WG to the EB refer to conditions that should be met by new plantations in order to ensure low GHG emissions during their operation.

Modifications to PalmGHG are still being made, notably to amend default values. Since PalmGHG is meant to support enlightened management, emphasis was put on including practice-related parameters and enabling field-measurement input data, wherever possible. However, numerous parameters are still not enough sensitive to site-specific conditions (e.g. $\mathrm{N}_{2} \mathrm{O}$ IPCC coefficients, POME or Peat-related emissions, biomass stands etc.). PalmGHG should be updated regularly to introduce updated parameters based on future reported effi- 
cient and robust empirical models and new scientific knowledge. RSPO Emission Reduction Working Group is presently working on establishing specific guidance to check for consistency of user-defined parameters and overall calculations, as well as procedures to program and validate regular updates of PalmGHG.

\section{Acknowledgements}

The authors are very grateful to all who participated in the second RSPO GHG WG for their contributions. We thank the companies who took part in the pilot phase for supplying data and feedback on the tool. Lastly, we are most grateful to members of the RSPO Executive Board for their continuing support; particular thanks being due to Dr Simon Lord for proposing the adoption of the GWAPP model and to Dr Timothy

Killeen for guiding the development of the GHG tool. We also wish to thank the reviewers, whose comments have led to major improvements in the paper.

\section{References}

Achten, W. M. J., Vandenbempt, P., Almeida, J., Mathijs, E., Muys, B., 2010a. Life Cycle Assessment of a Palm Oil System with Simultaneous Production of Biodiesel and Cooking Oil in Cameroon. Environ. Sci. Technol. 44(12), 4809-4815.

Achten, W. M. J., Almeida, J., Fobelets, V., Bolle, E., Mathijs, E., Singh, V. P., Tewari, D. N., Verchot, L. V., Muys, B., 2010b. Life cycle assessment of Jatropha biodiesel as transportation fuel in rural India. Appl. Energy 87(12), 3652-3660.

Arvidsson, R., Persson, S., Fröling, M., Svanström, M., 2011. Life cycle assessment of hydrotreated vegetable oil from rape, oil palm and Jatropha. J. Clean Prod. 19(2-3), 129-137.

Asmara, D. H., Khasanah, N., Agus, F., van Noordwijk, M., 2012. Oil palm plantation carbon stock calculator. World Agroforestry Centre ICRAF-SEA Regional Programme and Indonesian Soil Research Institute.

Bessou, C., Vélu, A., Caliman, J.P. 2012. LCA of Palm Oil in Sumatra, Comparison of Cropping Systems. ICOPE Conference, 22-24 February 2012, Nusa Dua, Bali, Indonesia

BSI, (2011) PAS2050 Specification for the assessment of the life cycle greenhouse gas emissions of goods and services. The British Standards Institution, London. ISBN 9780580713828.38 p

Chase, L.D.C., Henson, I.E., 2010. A detailed greenhouse gas budget for palm oil production. Int. J. Agric. Sustain. 8(3), 199-214. 
Chase, L., Henson, I., Abdul-Manan, A., Agus, F., Bessou, C., Milà i Canals, L., Sharma, M., 2012.

PalmGHG Calculator: A greenhouse gas accounting tool for palm products, Beta-version. The Roundtable for Sustainable Palm Oil - RSPO. Kuala Lumpur. Tool and accompanying documentation are available from http://www.rspo.org/en/rspo_palmghg calculator, and http://www.rspo.org/file/RSPO PalmGHG\%20Beta\%20version\%201.pdf

Chavalparit, O., Rulkens, W. H., Mol, A. P. J., Khaodhair, S., 2006. Options for environmental sustainability of the crude palm oil industry in Thailand through enhancement of industrial ecosystems. Environ. Dev. Sustain. 8(2), 271-287.

Cherubini, F., Strømman, A. H., Ulgiati, S., 2011. Influence of Allocation Methods on the Environmental Performance of Biorefinery products—A Case Study. Resour Conserv Recy. 55(11) 1070-1077.

Cherubini, F., Guest, G., Strømman, A. H., 2012. Application of Probability Distributions to the Modeling of Biogenic $\mathrm{CO}_{2}$ Fluxes in Life Cycle Assessment. GCB Bioenergy. 4(6) 784-798.

Choo, Y. M., Muhamad, H., Hashim, Z., Subramaniam, V., Puah, C. W., Tan, Y., 2011. Determination of GHG contributions by subsystems in the oil palm supply chain using the LCA approach. Int. J. Life Cycle Assess. 16, 669-681.

Chuchuoy, K., Paengjuntuek, W., Usubharatana, P., Phungrassami, H., 2009. Preliminary Study of Thailand Carbon Reduction Label: A Case Study of Crude Palm Oil Production. Eur. J. Sci. Res. 34(2), 252-259.

Couwenberg, J., 2011. Greenhouse gas emissions from managed peat soils: is the IPCC reporting guidance realistic? Mires and Peat. 8(Art. 2), 1-10.

Environment Agency, 2002. Guidance on Landfill Gas Flaring. UK Environment Agency, Bristol.

EPA (2012) Final Directive on Palm Oil. RFS2. Federal Register / Vol. 77, No. 18 / Friday, January 27, 2012 / Notices. US GPO, Washington, DC 20401

European Union Commission, 2009. Directive 2009/28/EC Draft Annex V. Draft Commission Decision (of 31 December 2009) on guidelines for the calculation of land carbon stocks for the purpose of Annex V of Directive 2009/28/EC. European Commission, Brussels. 26 p.

Fearnside, P. M., 2002. Time Preference in Global Warming Calculations: A Proposal for a Unified Index. Ecol Econ. 41(1) 21-31. 
Germer, J., Sauerborn, J., 2008. Estimation of the impact of oil palm plantation establishment on greenhouse gas balance. Environ. Dev. Sustain. 10(6), 697-716.

Germon J.C., Arrouays D., Deseau S., Félix I., Gabrielle B., Ganteil A., Gallienne J., Lellahi A., Lecorre N., Martin M., Mary B., Métay A., Nicolardot B., Quéré L., Reau R., (2007) Évaluation des impacts environnementaux des Techniques Culturales Sans Labour en France. Synthèse du groupe de travail sur le «bilan effet de serre ». ADEME-ARVALIS Institut du végétal-INRA-APCA-AREAS-ITB-CETION-IFVV. 400p.

Gnansounou, E., Dauriat, A., Villegas, J., Panichelli, L., 2009. Life Cycle Assessment of Biofuels: Energy and Greenhouse Gas Balances. Bioresource Technol. 100(21) 4919-4930.

Gurmit, S., 1995. Management and utilisation of oil palm by-products. The Planter 71, 361-386.

Harris, N., Grimland, S., Brown, S., 2009. Land Use Change and Emission Factors: Updates Since the RFS Proposed Rule. Winrock International. Report submitted to EPA. Available at: http://www.regulations.gov/\#!documentDetail;D=EPA-HQ-OAR-2005-0161-3163

Harsono, S.S., Prochnow, A., Grundmann, P., Hansen, A., Hallmann, C., (2012) Energy balances and greenhouse gas emissions of palm oil biodiesel in Indonesia. Glob. Change Biol. Bioenerg. 4, 213-228

Henson, I.E., 2005. OPRODSIM, a versatile, mechanistic simulation model of oil palm dry matter production and yield. In: Proceedings of PIPOC 2005 International Palm Oil Congress, Agriculture, Biotechnology and Sustainability Conference, 801-832. Kuala Lumpur: Malaysian Palm Oil Board.

Henson, I.E., 2009. Modelling carbon sequestration and greenhouse gas emissions associated with oil palm cultivation and land-use change in Malaysia. A re-evaluation and a computer model. MPOB Technology, 31, 116 pp.

IPCC, 2006. Guidelines for National Greenhouse Gas Inventories. Vol 4 Agriculture, Forestry and Other Land Use. WMO/UNEP. http://www.ipcc-nggip.iges.or.jp/public/2006gl/index.html.

IPCC, 2007. Fourth Assessment Report. Climate Change 2007 - Synthesis Report. WMO/UNEP. http://www.ipcc.ch/ipccreports/ar4-syr.htm.

Khasanah, N., van Noordwijk, M., Ekadinata, A., Dewi, S., Rahayu, S., Ningsih, H., Setiawan, A., Dwiyanti, E., Octaviani, R., 2012. The carbon footprint of Indonesian palm oil production. Technical Brief No 25: palm oil series. Bogor, Indonesia. World Agroforestry Centre - ICRAF, SEA Regional Office. 10p. 
Lasco, R.D., Sales, R.F., Estrella, R., Saplaco, S.R., Castillo, L.S.A., Cruz, R.V.O., Pulhin, F.B., 2001. Carbon stocks assessment of two agroforestry systems in the Makiling Forest Reserve, Philippines. Philippine Agri. Scientist. 84, 401-407.

Milà i Canals, L., Rigarlsford, G., Sim, S., 2013. Land use impact assessment of margarine. Int. J. Life Cycle Assess. 18(6) 1265-1277.

Müller-Wenk, R, Brandão, M., 2010. Climatic Impact of Land Use in LCA—carbon Transfers between Vegetation/soil and Air. Int. J. Life Cycle Assess. 15(2) 172-182.

Oil World, 2012. Statistics based on the Oil World forecasts. ISTA Mielke GmnH, Hamburg, Germany. Webpage http://www.oilworld.biz accessed on January 2013.

Page, S., Rieley, J. O., Banks, C. J., 2011. Global and regional importance of the tropical peatland carbon pool. Glob. Change Biol. 17(2), 798-818.

Pleanjai, S., Gheewala, S. H., Garivait, S., 2009. Greenhouse gas emissions from the production and use of palm methyl ester in Thailand. Int. J. Glob. Warm. 1(4), 418-431.

Rabl A., Benoist A., Dron D., Peuportier B., Spadaro J.V., Zoughaib A., 2007. How to Account for $\mathrm{CO}_{2}$ Emissions from Biomass in an LCA, Int. J. Life Cycle Assess. 12(5), 281.

Reijnders, L., Huijbregts, M. A. J., 2008. Palm oil and the emission of carbon-based greenhouse gases. J. Clean Prod. 16(4), 477-482.

RSPO, 2013. CSPO market performance (Feb 2013). Open publication accessed on 28/03/2013: http://www.rspo.org/en/key_statistics

RSPO PLWG 2012. RSPO manual on best management practices (BMP) for existing oil palm cultivation on peat. Ver 12.6 Final draft, $29^{\text {th }}$ Feb 2012. 142pp

Schmidt, J.H., (2007) Life cycle inventory of rapeseed oil and palm oil. PhD Thesis: Life cycle inventory report. Department of Development and Planning, Aalborg University, Aalborg, Denmark

Searchinger, T., Heimlich, R., Houghton, R. A., Dong, F., Elobeid, A., Fabiosa, J., Tokgoz, S., Hayes, D., Yu, T.-H., 2008. Use of U.S. Croplands for Biofuels Increases Greenhouse Gases Through Emissions from Land-Use Change. Science. 319(5867) 1238-1240. 
Seguin B., Arrouays D., Balesdent J., Soussana J.F., Bondeau A., Smith P., Zaehle S., de Noblet N., Viovy N. (2007) Moderating the impact of agriculture on climate, Agr. Forest Meteorol. 142, 278-287.

Siangjaeo, S., Gheewala, S. H., Unnanon, K., Chidthaisong, A., 2011. Implications of land use change on the life cycle greenhouse gas emissions from palm biodiesel production in Thailand. Energ. Sust. Dev. 15(1), 17.

Soussana, J.F., Loiseau P., Vuichard N., Ceschia E., Balesdent J., Chevallier T., Arrouays A. (2004) Carbon cycling and sequestration opportunities in temperate grasslands, Soil Use Manage. 20, 219-230.

Stichnothe, H., Schuchardt, F., 2011. Life cycle assessment of two palm oil production systems. Biomass Bioenerg. 35(9), 3976-3984.

Thamsiriroj, T., Murphy, J. D., 2009. Is it better to import palm oil from Thailand to produce biodiesel in Ireland than to produce biodiesel from indigenous Irish rape seed? Appl. Energy 86(5), 595-604.

van Noordwijk, M., Dewi, S., Khasanah, N., Ekadinata, A., Rahayu, S., Caliman, J-P., Sharma, M., Suharto, S., 2010. Estimating the carbon footprint of biofuel production from oil palm: Methodology and results from two pilot areas in Indonesia. Paper presented at: 2nd International Conference on Oil Palm and Environment (ICOPE) 2010, Bali, Indonesia.

Vijaya, S., Ma, A. N., Choo, Y. M., Nik, M. N. S., 2008. Life cycle inventory of the production of crude palm oil - A gate to gate case study of 12 palm oil mills. J. Oil Palm Research. 20, 484-494.

Wetlands International, 2010. A quick scan of peatlands in Malaysia. Wetlands International-Malaysia: Petaling Jaya, Malaysia. 74 pp.

Wicke, B., Dornburg, V., Junginger, M., Faaij, A., 2008. Different palm oil production systems for energy purposes and their greenhouse gas implications. Biomass Bioenerg. 32(12), 1322-1337.

Yacob, S., Hassan, M. A., Shirai, Y., Wakisaka, M., Subash, S., 2005. Baseline study of methane emission from open digesting tanks of palm oil mill effluent treatment. Chemosphere 59(11), 1575-1581.

Yacob S., Hassan M.A., Shirai Y., Wakisaka M., Subash S., 2006. Baseline study of methane emission from anaerobic ponds of palm oil mill effluent treatment. Sci. Total Environ. 366: 187-196.

Yusoff, S., Hansen, S., 2007. Feasibility Study of Performing a Life Cycle Assessment on Crude Palm Oil Production in Malaysia (9 pp). Int. J. Life Cycle Assess. 12(1), 50-58. 
Zamagni, A., Guinée, J., Heijungs, R., Masoni, P., Raggi, A., (2012) Lights and shadows in consequential LCA. Int. J. Life Cycle Assess. 17(7), 904-918.

\section{Tables}

Table 1. Carbon stocks (below- and above-ground biomass) for the land uses available in PalmGHG

\begin{tabular}{|c|c|c|}
\hline Land uses & $\begin{array}{l}\text { Carbon stocks } \\
\text { in tonne } \mathrm{C} / \mathrm{ha}\end{array}$ & Reference and origin of data \\
\hline Primary forest & 225 & $\begin{array}{l}\text { Mean of } 62 \text { values from the literature adjusted to include roots (Henson, 2012, } \\
\text { unpublished database) }\end{array}$ \\
\hline Logged forest & 87 & Henson, 2005a; Henson, 2009 \\
\hline Coconut & 75 & European Commission, 2009 \\
\hline Rubber & 62 & $\begin{array}{l}\text { Yew, 2000; Yew and Nasaruddin, 2002; Henson, 2009, Data are for a mature } \\
\text { ( } 29 \text { year old) stand and were adjusted to allow for C sequestered in harvested } \\
\text { rubber wood. }\end{array}$ \\
\hline Cocoa under shade & 70 & Lasco et al., 2001. Data were adjusted to include roots \\
\hline Oil palm & $\geq 50$ & $\begin{array}{l}\text { Calculated using the OPPRODSIM and OPCABSIM models (Henson, 2005b, } \\
\text { 2009), with actual amounts dependant on crop age and growth conditions } \\
\text { (vigorous or average). The value given here is for a } 30 \text { year old, vigorous stand. }\end{array}$ \\
\hline Secondary regrowth & 48 & Average of logged forest and food crops \\
\hline Shrub & 26 & WINROCK model (Harris et al., 2009) pers. com. N. Harris Data 2000 to 2007 \\
\hline Food crops & 9 & $\begin{array}{l}\text { Average of annual and perennial crops in Papua New Guinea where mixed } \\
\text { cultivation s practised (WINROCK model, Harris et al., } 2009 \text { and Harris pers. } \\
\text { com.) }\end{array}$ \\
\hline Grassland & 5 & Henson, 2009 \\
\hline
\end{tabular}

Table 2. Pilot mills, their main characteristics and GHG balances assessed with PalmGHG

\begin{tabular}{llllll}
\hline Mills $^{7}$ & $\begin{array}{l}\text { Mean yield } \\
\text { t FFB/ha }\end{array}$ & $\begin{array}{l}\text { Outgrowers } \\
\text { included }\end{array}$ & $\begin{array}{l}\text { Peat soil proportions } \\
\text { (own-growers only) }\end{array}$ & Previous land uses & C C \\
\hline A & 23.6 & no & $0 \%$ & Shrub & -0.02 \\
B & 22.8 & no & $0 \%$ & Shrub & 0.01 \\
C & 19.2 & no & $0 \%$ & Logged forest, grassland & 0.05 \\
D & 17.2 & yes & $0 \%$ & Mixture of previous land uses & 0.45 \\
E & 24.3 & no & $0 \%$ & Cocoa, oil palm & 0.83 \\
F & 17.2 & yes & $0.25 \%$ & Logged forest & 1.33 \\
G & 15.3 & yes & $0 \%$ & Mixture of previous land uses & 1.38 \\
H & 19.3 & no & $0 \%$ & Logged forest, oil palm & 1.97 \\
I & 24.2 & yes & $31 \%$ & Grassland, shrub & 2.39 \\
J & 18.5 & yes & $79 \%$ & Grassland, shrub & 8.32 \\
\hline
\end{tabular}




\section{Figures}

Figure 1. System boundary of PalmGHG

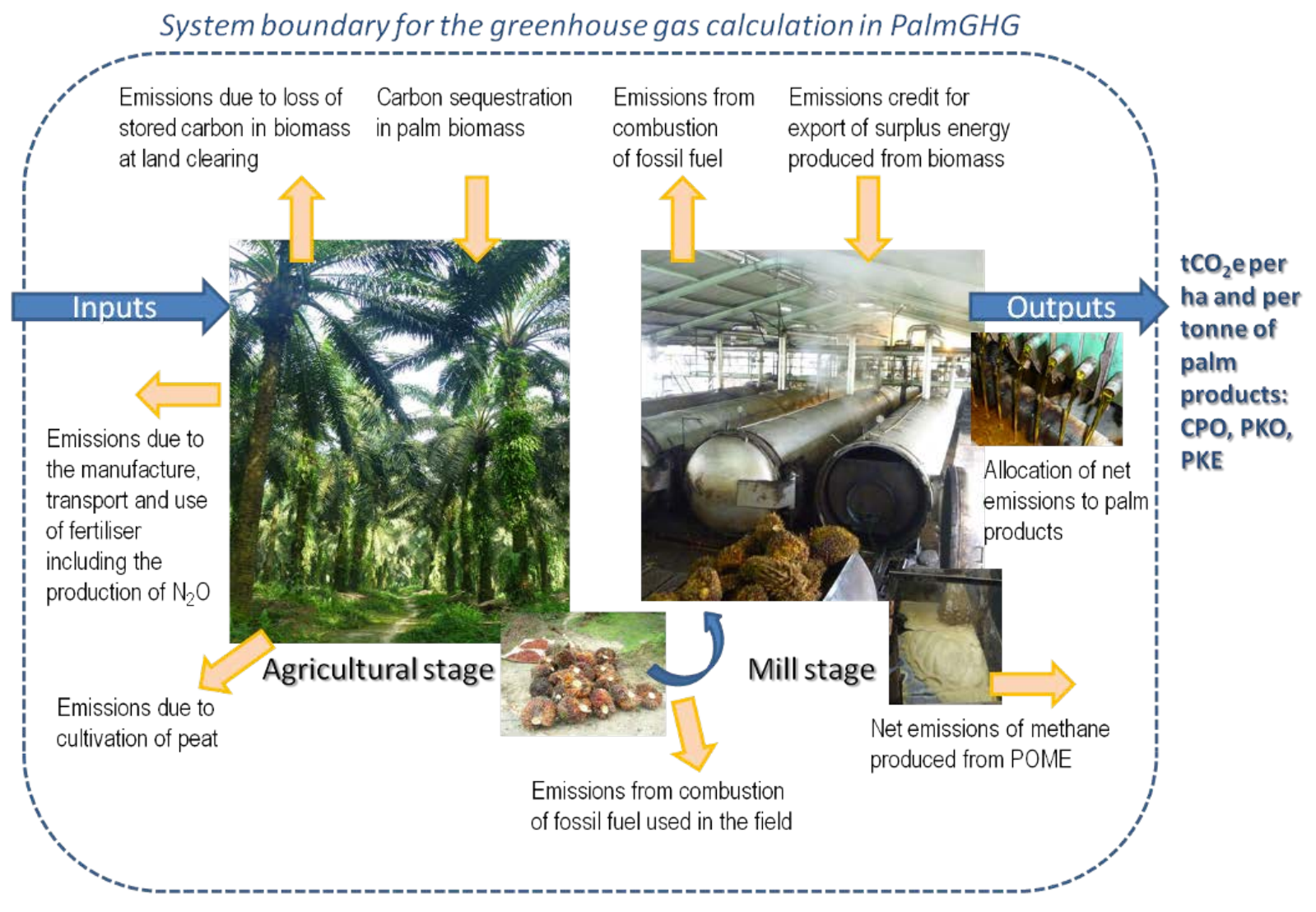


Figure 2. Contributions to GHG balance of mill $\mathrm{H}$ assessed with PalmGHG

The throughput of mill $\mathrm{H}$ is $86,200 \mathrm{tCPO} /$ year

Land clear. $=$ emissions due to the losses of carbon sequestrated in previous land use

Crop sequestration $=$ carbon sequestrated in palm oil stand

Fertilisers $=$ emissions from fertiliser production and transport to the user country

$\mathrm{N} 2 \mathrm{O}$ = field emissions related to $\mathrm{N}$-fertiliser application

Field fuel = emissions due to transport of inputs to the field, fertiliser spreading and fruit transport, part of worker transportation and field infrastructure maintenance

Peat $=$ emissions due to peat cultivation

POME $=$ methane emission during conventional POME digestion

Mill fuel $=$ fuel use at the mill stage

Mill credit = emission savings due to excess electricity production and distribution, or substitution allowed by coproducts (e.g. sold ashes to cement factory)

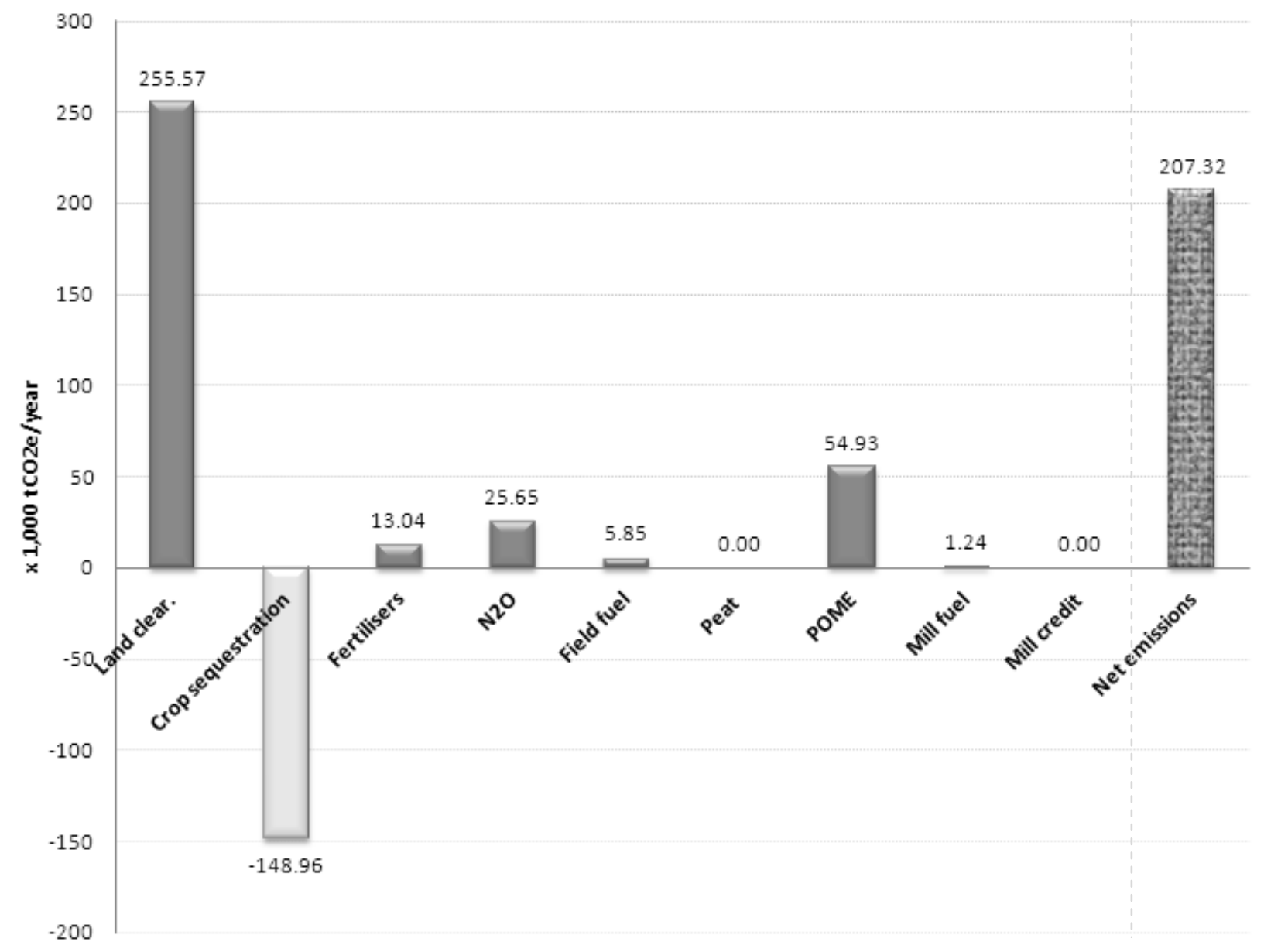


Figure 3. Contributions to GHG field emissions of mills G (a) and I (b) assessed with PalmGHG Land clear. $=$ emissions due to the losses of carbon sequestrated in previous land use Crop sequestration $=$ carbon sequestrated in palm oil stand Fertilisers $=$ emissions from fertiliser production and transport to the user country $\mathrm{N} 2 \mathrm{O}=$ field emissions related to $\mathrm{N}$-fertiliser application

Field fuel = emissions due to transport of inputs to the field, fertiliser spreading and fruit transport, part of worker transportation and field infrastructure maintenance

Peat $=$ emissions due to peat cultivation

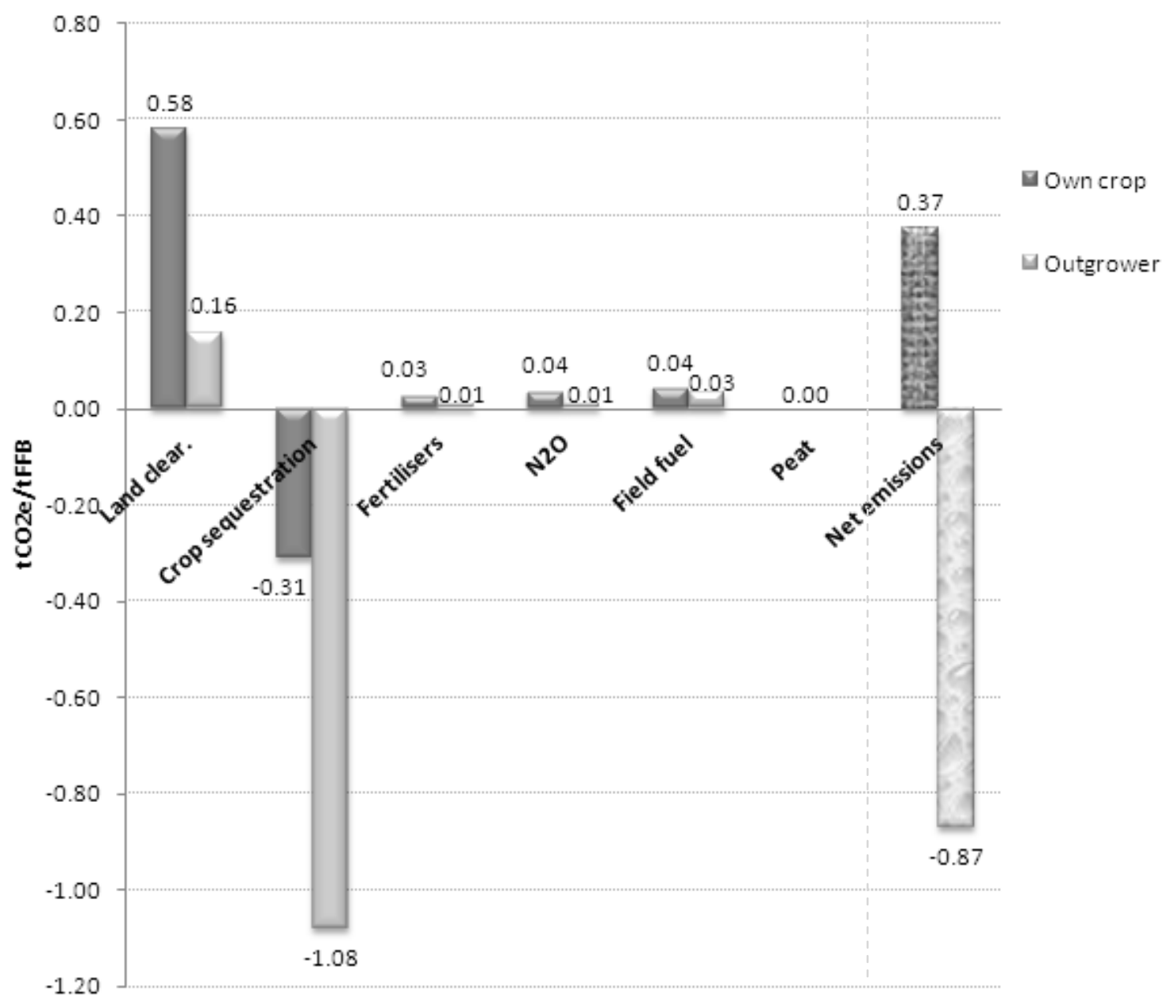

(a) 


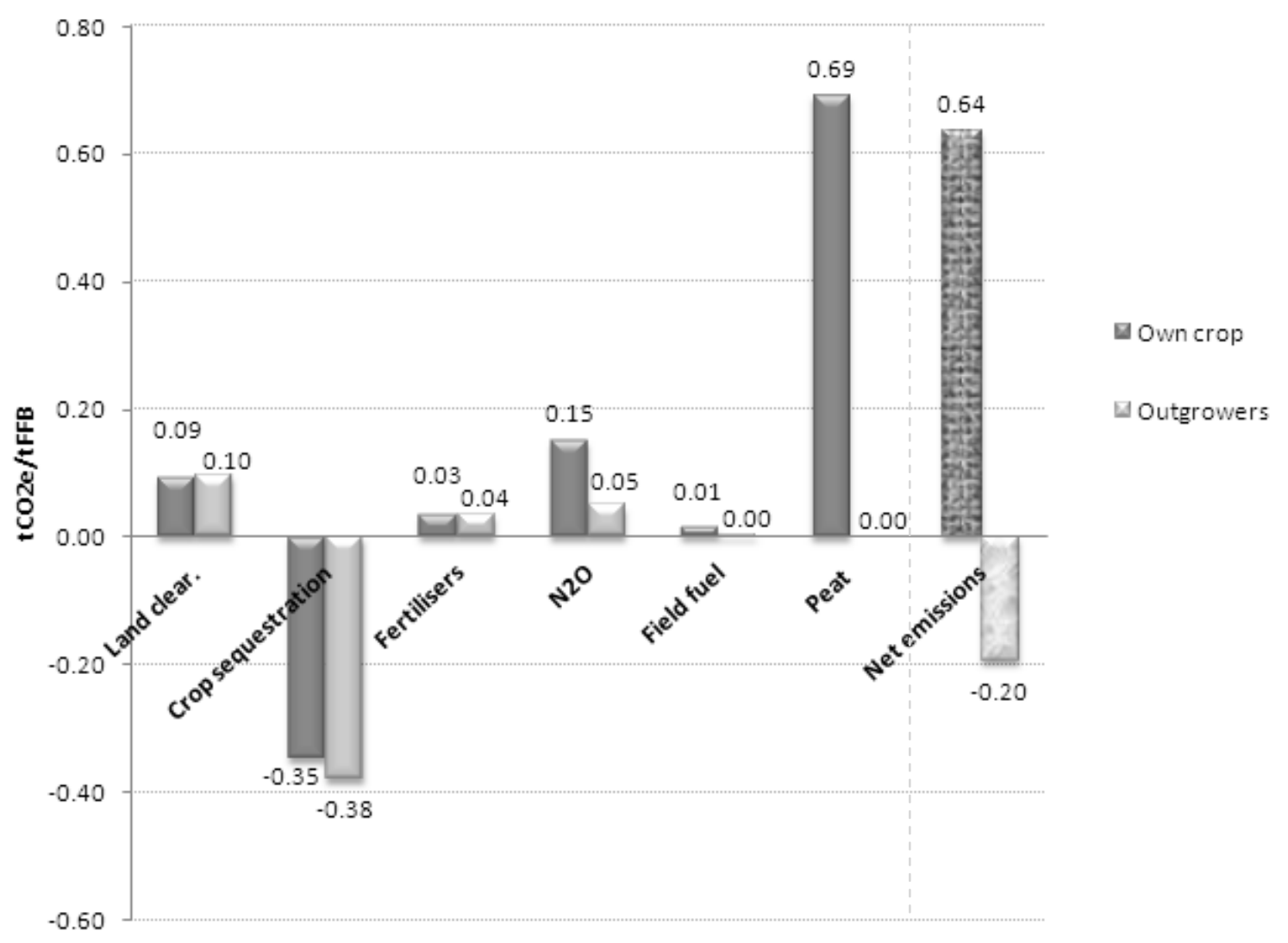

(b) 
Figure 4. Scenario testing with PalmGHG

Scenario base case (1): mixed previous land uses, peat 3\%, no POME treatment, OER 21\%, own crops mean yield 20 t FFB/ha, outgrowers' mean yield 14 t FFB/ha.

Scenario 2: $100 \%$ logged forest as previous land use on mineral soils

Scenario 3: $100 \%$ grassland as previous land use on mineral soils and arable crops on peat soils

Scenario 4: Capture and conversion of methane to electricity

Scenario 5: 100\% replant, no peat, capture and conversion of methane to electricity

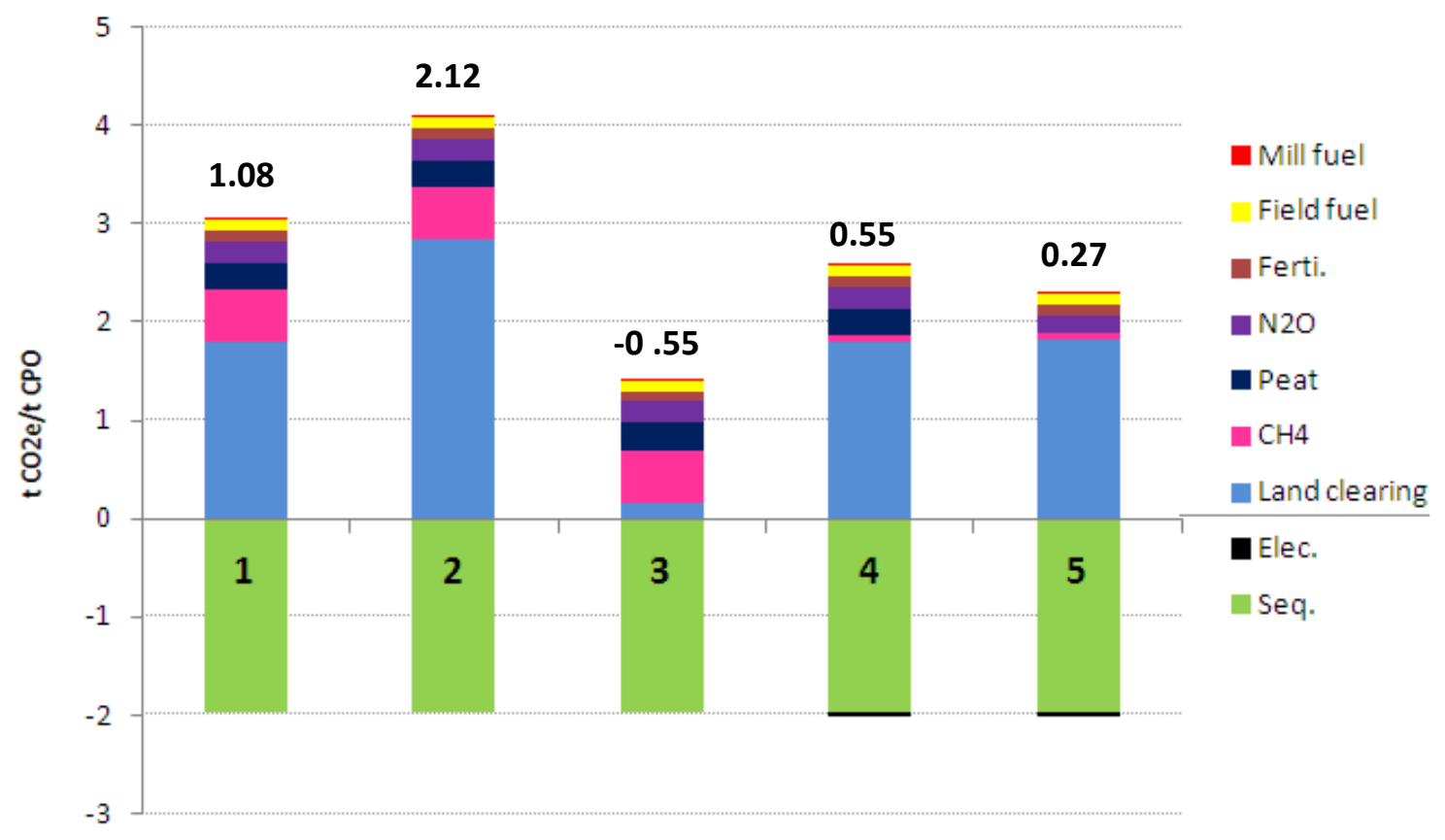

